Portland State University

PDXScholar

\title{
A Comparison of the Vocabulary Ability of Four- and Five-Year-Old Bilingual Mexican-American Children with That of Monolingual Anglo-American Children
}

Amparo Abila

Portland State University

Follow this and additional works at: https://pdxscholar.library.pdx.edu/open_access_etds

Part of the First and Second Language Acquisition Commons, and the Speech Pathology and Audiology Commons

Let us know how access to this document benefits you.

\section{Recommended Citation}

Abila, Amparo, "A Comparison of the Vocabulary Ability of Four- and Five-Year-Old Bilingual MexicanAmerican Children with That of Monolingual Anglo-American Children" (1976). Dissertations and Theses. Paper 2454.

https://doi.org/10.15760/etd.2451

This Thesis is brought to you for free and open access. It has been accepted for inclusion in Dissertations and Theses by an authorized administrator of PDXScholar. Please contact us if we can make this document more accessible: pdxscholar@pdx.edu. 
AN ABSTRACT OF THE THESIS OF Amparo Abila for the Master of Science in Speech Communication presented February 12, 1976.

Title: A Comparison of the Vocabulary Ability of Four- and Five-Year0ld Bilingual Mexican-American Children With That of Monolingual Anglo-American Children.

APPROVED BY MEMBERS OF THE THESIS COMMITTEE:

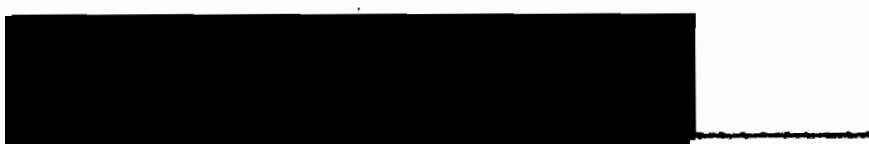

Robert H. English, ghairman

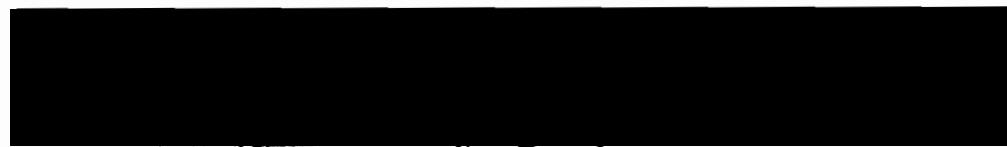

Jack tegrenes

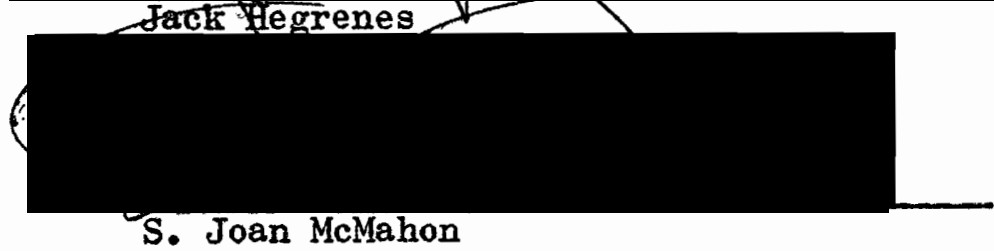

This study sought to investigate the Spanish and English receptive pictorial vocabulary of four- and five-year-old bilingual MexicanAmerican children. The performance of bilingual Mexican-American children on the Mexican-American Inventory of Receptive Abilities--MIRA (Nelson-Burgess and Meyerson, 1975) and the Peabody Picture Vocabulary Test--PPVT (Dunn, 1959) was compared to that of monolingual AngloAmerican children of the same relative age range and socioeconomic level. 
Forty-two subjects were included in this study. Twenty-one bilingual Mexican-American children between the ages of 4.0 years and 5.11 years were randomly selected from the Title $1 \mathrm{M}$ Summer School at Nellie Miur Grade School in Woodburn, Oregon. The control group was composed of twenty-one monolingual Anglo-American children from the Barlow Child Development Center in Barlow, Oregon, the Woodburn Child Development Center in Woodburn, Oregon, and the Benedictine Child Development Center in Mt. Angel, Oregon. All these centers had the same socioeconomic qualification for accepting children, were geographically close to one another, and were located in rural areas. Children in the control group were matched within two months of the chronological age of the experimental group. Both the control and experimental subjects were screened for hearing acuity and the children's teachers were asked to eliminate any child they suspected might be intellectually deficient.

Since both groups of children achieved an almost perfect score on the modified MIRA, it is believed this test was unable to measure accurately the receptive pictorial vocabulary performance of these children. Furthermore, the results of this test did not illustrate any distinction between the vocabulary performance of the experimental group in English and Spanish. Hence, all findings relative to this test were statistically nonsignificant.

The authors reported the MIRA was currently being used as a screening instrument in the San Joaquin Valley of California. Unfortunately, based on the findings of this investigation, the modified MIRA cannot be used with confidence as a screening instrument for four- and five-year-old Mexican-American children in the Woodburn area of Oregon. 
Since the oniy difference between the MIRA and the modified MIRA is that the modified MIRA was extended by translating the word lists into the other language, one might wonder about the effectiveness of the

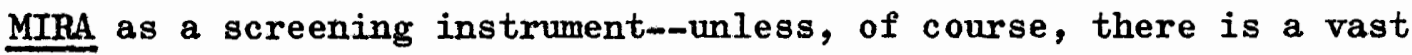
difference between Mexican-American children living in Oregon and those living in California. Perhaps the MIRA could be used with younger children; however, it would have to be tested empirically before one could reach this conclusion with confidence.

The raw scores for both the experimental and control groups on the PPVT, however, were statistically significant. Results revealed a significantly lower performance in the areas of receptive pictorial English vocabulary abilities of bilingual Mexican-American children when compared with monolingual Anglo-American children. A wide variation was found in the individual scores of the experimental group. Thus, a secondary finding in this study was Mexican-American children in Oregon, as in Texas (Carrow, 1971), are a heterogeneous group, and there is a wide range of abilities present in the receptive English pictorial vocabulary skills of these children.

Hickey (1972) proposed the theory that the difference between the raw scores of the two groups was due to the Mexican-American children's inability to respond correctly to the "ing" words on the PPVT; hence, their responses as a group to such words were examined. It was found that neither eliminating the "ing" words nor the "non-ing" words affected the results of this investigation. 
A COMPARISON OF THE VOCABULARY ABILITY OF FOUR- AND FIVE-YEAR-OLD BILINGUAL MEXICAN-AMERICAN CHILDREN WITH THAT OF MONOLINGUAL ANGLO-AMERICAN CHIIDREN

by

AMPARO ABILA

A thesis submitted in partial fulfillment of the requirements for the degree of.

MASTER OF SCIENCE IN SPEECH COMMUNICATION: with an emphasis in SPEECH PATHOLOGY/AUDIOLOGY

Portland State University

1976 
TO THE OFFICE OF GRADUATE STUDIES AND RESEARCH:

The members of the Committee approve the thesis of Amparo Abila presented February 12, 1976.

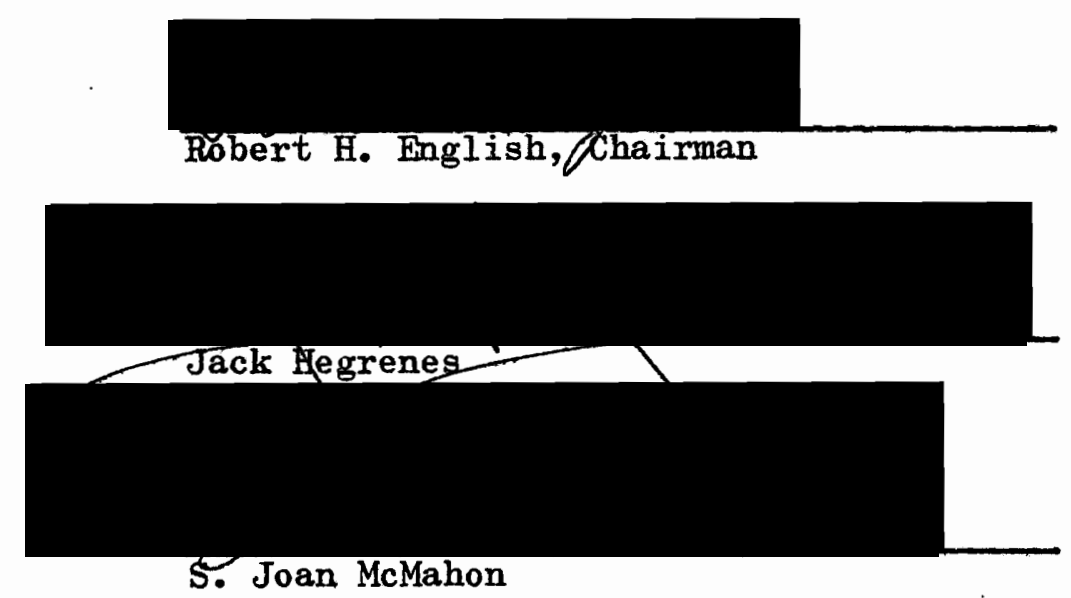

APPROVED:

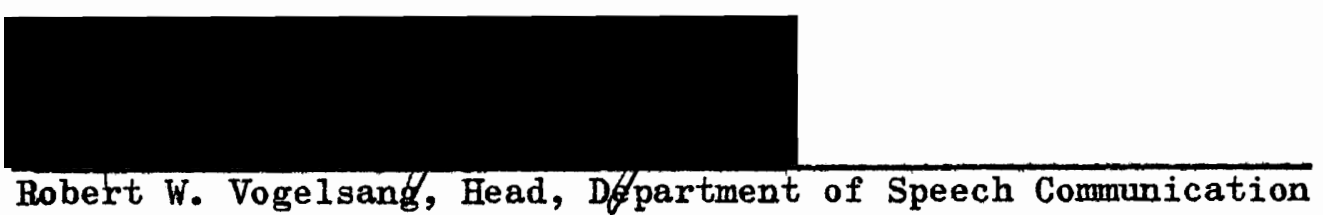

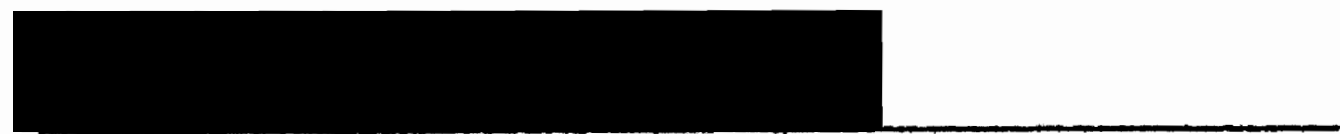

Richard B. Halley, Dean of Graduatef Studies and Research

February 24, 1976 


\section{ACKNOWLEDGMENTS}

Many have encouraged me and without them this thesis could not have been written. I would especially like to thank my thesis advisor, Dr. English, for all his caring and many long hours of hard work. A special thank you to: Joan McMahon for her sense of humor and good practical suggestions; Dr. Hegrenes for sharing his enthusiasm and knowledge of statistics with me; and Dr. Casteel, although he wasn't on my committee, for his interest and concern.

I also would like to thank the parents of the children who participated in this experiment and the personnel of the Barlow Child Development Center, the Benedictine Child Development Center, the Nellie Muir 1M Summer School, and the Woodburn Child Development Center, for so graciously allowing me to test their children.

My gratitude and appreciation go to my friends for their faith and confidence in me, especially Bobbie and Shirley. To my children, Robert and Kathy, thank you for your love, support, and understanding; without your cooperation nothing could have been accomplished. 
TABLE OF CONTENTS

PAGE

ACKNOWLEDGMENTS . . . . . . . . . . . . . . . . . . iii LIST OF TABLES . . . . . . . . . . . . . . . • • vi

CHAPTER

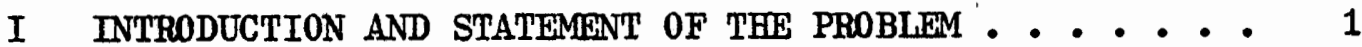
INTRODUCTION ................ 1 STATEMENT OF THE PROBLEM . . . . . . . . 3 QUESTIONS TO BE ANSWERED . . . . . . . . . 4 OPERATIONAL DEFINITIONS ........... 4

II REVIEW OF THE LITERATURE . . . . . . . . . 6

BICULTURALISM AND POVERTY . . . . . . . . . 6 BILINGUALISM ............... 8 TESTS OF BILINGUALISM . • • • • • • . . . 11 TESTS OF LANGUAGE . • • • . • • • . . . 15 SUMMARY .................. 20

III METHODS AND PROCEDURES . . . . . . . . . . 21 SUBJECTS . . . . . . . . . . . . 21 VARLABLES ................. 21 Age Sex

Intelligence

Socioeconomic Status Auditory Acuity

INSTRUMENTS ................ 22 
CHAPTER

PAGE

PROCEDURES

TEST ADMINISTRATION • • • • • • • • • • • • 25

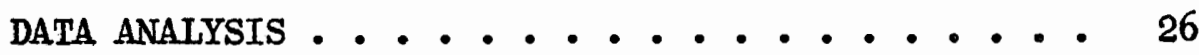

IV RESULTS AND DISCUSSION OF RESULTS • • • • • • • • • • $\quad 27$

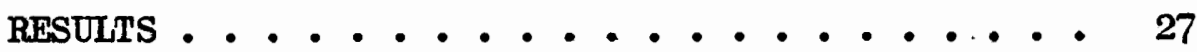

Mexican-Amexican Inventory of Receptive Abilities

Peabody Picture Vocabulary Test

DISCUSSION .................. 34

Pexformance of Mexican-American and

Anglo-American Children on the MIRA

Performance of Mexican-American and

Anglo-American Children on the PPVT

V SUMMARY AND IMPLICATIONS . . . . . . . . . 40

SUMMARY ................ 40

IMPLICATIONS ............. 42

BIBLIOGRAPHY ... . . . . . . . . . . . . . 44

APPENDICES . . . . . . . . . . . . . . . . . 51

A ELIGIBILITY CRITERIA FOR TITLE IM NELLIE MUIR

SUMMER SCHOOL . . . . . . . . . . . . 52

B ELIGIBILITY/FEE SCALE (POTENTIAL RECIPIENTS) • • • - 53

C MIRA RESPONST SHEET . . . . . . . . . . . 54

D PILT STUDY . . . . . . . . . . . . . 56

E MODIFIED MIRA TEST . . . . . . . . . . . 57

F PEABODY PICTURE VOCABULARY TEST . . . . . . . . . 58

G PERMISSION REQUEST . . . . . . . . . . . 60

H PERMISSTON REQUEST - . . . . . . . . . 61 


\section{LIST OF TABLES}

TABLE

PAGE

I TEST RESULTS FROM THE MIRA SHOWING MEAN RAW SCORES FOR BOTH THE EXPERIMENTAL AND CONTROL GROUPS

II TEST RESUTIS ON THE PPVT SHOWTNG INDIVIDUAL RAW SCORES FOR BOTH THE EXPERTMENTAL AND CONTROL SUBJECTS

III COMPARISON OF RAW SCORES ON PPVT SHOWING MEANS, STANDARD DEVLATIONS, AND $t$-TEST RESULTS FOR BOTH THE EXPERIMENTAL AND CONTROL GROUPS . . . . . 31

IV COMPARISON OF CORRECT "ING" WORDS ON PPVT SHOWING MEANS, STANDARD DEVIATIONS, AND t-TEST RESULTS FOR BOTH THE EXPERIMENTAL AND CONTROL GROUPS . . . . 33

V COMPARISON OF CORRECT "NON-ING" WORDS ON PPVT SHOWING MEANS, STANDARD DEVIATIONS, AND T-TEST RESULTS FOR BOTH THE EXPERIMENTAL AND CONTROL GROUPS . . . . . 33 


\title{
CHAPTER I
}

\author{
INTRODUCTION AND STATEMENT OF THE PROBLEM
}

\section{INTRODUCTION}

The role bilingualism plays in the life of a Mexican-American child is being investigated by psychologists, linguistists, sociologists, educators, and speech pathologists. These various disciplines are looking into the possible effects of bilingualism on the mental, emotional, linguistic, and educational development of the MexicanAmerican child.

Mexican-Americans, with a population of over six million, are the second largest minority in the United States (Bureau of Census, 1974). During the period 1971-72 over a hundred thousand people legally entered the United States from Spanish speaking countries. The United States now has the fifth largest population of Spanish speaking people in the Americas; only Mexico, Argentina, Colombia, and Peru have larger Spanish speaking populations. While the median age for Anglo-Americans is 28 years, it is 18.6 years for Mexican-Americans; and the birthrate of the Spanish speaking population in the United States is nearly twice as bigh as that of the English speaking population. Thus, further increases in the Mexican-American population can be expected (Gonzales, 1973).

Between the years 1968-70 the total number of children attending public schools in the United States increased by 3.5 per cent; the 
number of Spanish speaking children increased by approximately 13.6 per cent; thus, the Spanish speaking population increased at a rate almost four times greater than the national average (Gonzales, 1973).

The scholastic pattern of the Mexican-American child has been characterized by poor academic achievement and high "drop-out" rates (Casey, 1974). Although Mexican-Americans total 12 per cent of the school population, 50 per cent "drop out" before completing a' high school education and less than 1 per cent enter college. The average educational level for Mexican-Americans over the age of twenty-one is at the eighth grade level (Bureau of Census, 1974).

Carrow (1971) states the "language handicap" is considered the most significant factor responsible for the reported mental, social, and educational problems of the Mexican-American child. Sanchez (1967) supports this contention in a more illustrative manner when he writes:

Imagine the Spanish speaking child's introduction to American education. He comes to school, not only without a word of English but without the evironmental experience upon which school life is based.

If these Mexican-American children have not mastered English or Spanish, Holland (1960) believes they must be thought of as being, substandard or partial speakers of Spanish and English rather than as fully bilingual. He notes there are two distinct types of language problems:

1. The monolingual Spanish speaking child, who only speaks Spanish and does not know English. If this child is taught English or placed in a bilingual classroom, he can function in the American school system.

2. The largest group is composed of bicultural children. These children have learned substandard English language patterns from other "disadvantaged children." 
The bicultural or bilingual child's language patterns will resemble those from whom he first learned his language, whether it be the language pattern of a poor white or a black. Sherk (1969) states ". . 'ghetto' children bring to school the language of the community into which they were born."

Baltaxe (1974) and Toronto (1974) believe a distinction must be . made between the bilingual and the language deviant child. To make this kind of diagnosis, however, the child must be tested in both languages. The problem of adequately evaluating the Mexican-American child is complicated by the limited availability of standardized, developmental language tests which are valid for Spanish speaking children. Hence, with the rise in population and increased awareness of the Mexican-American child's language problem, it has become vitally important to assess this child's language development not only in English but in Spanish as well. To do this tests must be developed, ralidated, revalidated, and administered before they can be used with confidence to estimate the educational, linguistic, mental, or emotional and social levels of the rising Mexican-American population within an English speaking environment. Hence, this investigation has focused upon the feasibility of using tests such as the MIRA and the PPVI in order to plan educational strategies for Mexican-American children.

\section{STATEMENT OF THE PROBLEM}

The purpose of this investigation was to compare the results of two language tests administered to Mexican-American children. More specifically, the Peabody Picture Vocabulary Test--PPVT (Dunn, 1959) 
and both the English and Spanish portions of a modified version of the Mexican-American Inventory of Receptive Abilities--MIRA (Nelson-Burgess and Meyerson, 1975) were administered to an experimental group of bilingaal, four- and five-year-old Mexican-American children. Additionally, the PPVT and the modified English portion of the MIRA were administered to a control group of monolingual, four- and five-year-old Anglo-American children. Scores obtained were then analyzed between and within groups.

\author{
QUESTIONS TO BE ANSWERED
}

The specific questions this investigation sought to test were:

1. Do Mexican-American children perform the same on the Spanish portion of the modified MIRA as on the Fnglish portion?

2. Do Mexican-American children perform the same on the English portion of the modified MIRA as do the AngloAmerican children?

3. Do Mexican-American children perform the same on the Spanish portion of the modified MIRA as Anglo-American children do on the English portion of the modified MIRA?

4. Do Mexican-American children perform the same on the English portion of the modified MIRA as they do on the PPVT?

5. Do Mexican-American children perform the same on the Spanish portion of the modified MIRA as they do on the PPVT?

6. Do Mexican-American children perform the same on the PPVT as do the Anglo-American children?

\title{
OPERATIONAL DEFINITIONS
}

The following are operational definitions of specific terms employed in this investigation: 
Anglo-American: A person born in the United States whose native language is Bnglish and whose culture is of English origin.

Biculturalism: Mexican-American children whose parents speak Spanish in the home, and whose families live by or associate with other Mexican-American families that speak Spanish.

Bilingualism: Mexican-American children who, according to their teacher, understand both English and Spanish and who correctly respond in either English or Spanish to the following stimuli. (Six items were randomly presented in

English and six in Spanish. They had to respond correctly to four of the six items presented in each language. They could respond in either English or Spanish.)

1. What is your name?

2. How old are you?

7. Where do you live?

3. Do you have a brother?

8. Where is your mother?

4. Do you have a sister?

9. Do you have a pet?

5. Please close the door. 11. Show me your hand.

6. Sit in the chair. 12. Show me your foot.

Mexican-American: Any child of Mexican descent born in the United States.

Monolingual: Any Anglo-American child born in the United States whose native language is English, whose parents do not speak a foreign language, and who speaks only English. 


\section{CHAPTER II}

\section{REVIEW OF THE LITERATURE}

Recent studies of bilingualism and Mexican-American children include the problems involved in separating biculturalism and poverty from bilingualism, and also include investigations where tests were administered to Mexican-American children.

According to Carrow (1968) few experimental studies, particularly those involving direct measurement of language handicaps associated with bilingualism, have been conducted; and the results of those which have been made have not always been in agreement. Carrow reasons that the conflicting conclusions found in the various studies may be partly attributable to methodological difficulties associated with the area of bilingualism.

\section{BICUITURALISM AND POVERTY}

One major difficulty has been separating the effects of bilingualism from those of biculturalism and poverty. Many times the child is a member of an immigrant family whose culture affects the extent to which the family can participate in economic and educational opportunities (Lewis and Lewis, 1965).

According to the Department of Compensatory Education (1974), a subdivision of the Oregon Board of Education, at one time 45 per cent of the Mexican-American children in California were considered to be 
mentally retarded. The reasons for this evaluation are not stated; however, one may conjecture that it might possibly be the result of two major factors: 1) that there are very few valid and reliable tests in the Spanish language for Mexican-Americang; and 2) a large percentage of Mexican-American children are raised in low income, impoverished environments.

The Oregon Board of Education (1967) further notes that 30 or 40 per cent of the Mexican-American families residing in the United States earned less than $\$ 3,000$ per year. The average income of a MexicanAmerican male in 1973 was $\$ 5,978$ and for a female $\$ 2,388$ (Bureau of Census, 1974). Apparently, the income level for the Mexican-American male has risen; unfortunately, so has the rate of inflation. Thus, a large majority of these families are still living at or near the poverty level, especially if the head of the household is a woman.

The population of economically disadvantaged children, regardless of ethnic background, ranks especially high in the areas of prenatal deprivation, birth injury, nutritional deficit, childhood accident, and chronic illness (Kappleman, 1969). All these elements can be contributing factors in speech and language disorders; thus, due to poor medical attention and inadequate nutrition, the incidence of speech and language disorders tends to be higher among these economically disadvantaged children (Casey, 1974). Hence, when Mexican-American children are included in the category of economically disadvantaged, the chances of speech and language disorders being present, where not attributable to bilingual factors, are greatly increased. 


\section{BILINGUALISM}

Bourgeois (1974) and Toronto (1974) emphasize that for most poverty stricken people involved in survival, abstract middle class language skills tend to be of secondary importance, and motivation for this kind of language learning generally may be low. Since the state of socioeconomic disadvantage is frequently associated with a lack of knowledge of the Bnglish language, bilingualism is almost always interpreted as a language handicap (Sanchez, 1967). The definition of bilingualism, however, may vary from investigation to investigation. Some of these definitions include:

... native-like control of two languages (Bloomfield, 1933).

- . the ability to produce meaningful and complete utterances in the other language (Haugen, 1953).

.. the practice of alternately using two languages (Weinreich, 1963).

- . persons who possess at least one of the language skills even to a minimal degree in their second language (Macnamara, 1967).

- . using or capable of using two languages, often with equal facility (Webster, 1968). -. performance at the age mean or above in both languages (Carrow, 1971).

-. the language user's linguistic competence which cannot be described by a single grammar (Wald, 1973).

While Macnamara (1967) views bilingualism as a continuum which varies among individuals along a variety of dimensions such as speaking, listening, reading, and writing, Weinreich (1963), Webster (1968), and Wald (1973) suggest equal facility in both languages is common but 
separate. The ability to maintain linguistic independence varies anong bilingual communities, individuals within a community, and even within an individual's performance depending upon the occasion, topic, environment, et cetera (Mackey, 1962; Gumperz, 1964; Ervin-Tripp, 1964). Penfield and Roberts (1959) attempted to explain linguistic independence with the theory that the neurological systems underlying the two languages of bilinguals function separately. This theory , implies a single switching system. Thus, when the neurological system of one language is on, the other is off. In 1965, Preston suggested a two switch model to explain functional separation. He argues that since a bilingual can decide which language to speak regardless of his environment, it is as though he had a language switch controlling his language output system. During the decoding process, when he sees or hears words in one of the two languages he kmows, he automatically uses the appropriate input system for the language. Thus, it is as though there is a language switch at the beginning of his input or decoding system which the environment controls.

Macnamara (1967) believes linguistic independence is dependent upon language being a highly distinctive and overlearned coding system. Koler (1965), however, notes that language, besides being a set of coding categories, also consists of words and rules for joining these words. This combination of words and rules forms a linguistic system which enables one to deal with the environment (Miller, Galanter, and Pribram, 1960). At this time, however, the complete process of 1 inguistic independence cannot be explained.

The opposite of linguistic independence is linguistic interfer- 
ence. This is the tendency for the phonological, lexical, syntactical, and semantic systems of one language to become involved with those of another. Although switching from one language to another is part of the bilingual's skill, it may take the form of linguistic interference. There are both linguistic and nonlinguistic cues which guide the bilingual in his choice of language. Whether these cues are available or not, the bilingual can consciously decide when and where to use each language. At times, however, the linguistic or nonlinguistic cues can be so powerful that the bilingual unconsciously may switch from one language to another without being aware of his linguistic shift (Macnamara, 1967).

A distinction between stable and unstable bilingual situations has been made by Fishman (1968). Stable bilingual situations are characterized by language maintenarice, which is the continuation of using both languages in the same maniner and degree. An unstable language situation is where one language displaces the other language. This occurs when the individual is becoming more dependent on one language and is not using both languages in the same manner and degree as he previously did. The maintenance of language stability does not imply, however, that the person is equally competent in any two languages or even competent in one language.

\section{TESTS OF BILINGUALISM}

A traditional measure of the degree of bilingualism has been to subtract the test score obtained in one language from the test score obtained in the other. A person whose score is the same in each 
known-hence, the lower the scores on the FRPVT. This would tend to indicate that the Hoffman Bilingual Schedule might be a relatively sensitive predictor of the degree of Spanish utilized in the home. Although it is difficult to know how valid is the described linguistic background, the reliability of the background questionnaire type of measure appears to be quite high; however, whether language skills validly can be predicted in this manner is still unknown at this time. The experimenter can rate the bilingual's language skills either receptively (how much language is understood) or expressively (how well a language is spoken or written). Typically, language background ratings and language skill ratings correlate highly (Macnamara, 1967). The Richness of Vocabulary Test (Macnamara, 1967), a flexibility measure, appears to give a better indication of the subject's competence in both languages than a rating of language skills test. In this flexibility test a subject is presented with a series of phrases in each language, e.g., "He is drunk," and the subject is then asked to write as many words or expressions as he can that are the same as the word underlined. Another flexibility test is Lambert's (1959) Word Detection Test. This test requires a subject to identify as many words as he can in a long nonsense word. In addition, the subject is presented with an ambiguous stimuli and asked to pronounce or interpret it. The assumption is that he will respond in his most fluent language. Fluency tests measure the speed of responding to verbal stimuli or the speed of verbal production in two languages. Ervin (1961) had bilingual subjects name pictures in both languages; Rao (1964) measured the speed with which bilinguals followed simple instructions in both 
languages; and Macnamara (1967) counted the different words subjects could say in one language and then the other within a certain time limit. The research of Lambert, Havelka, and Gardner (1959), Treisman (1965), and Kohlers (1966) lend support to the theory that the speed of translating and the degree of bilingualism are unrelated. Even Macnamara (1967) states in his study that the validity of this type of test to measure the degree of bilingualism is questionable. These findings would seem to indicate the speed of decoding and encoding is unrelated to the bilingual's overall language ability. Macnamara (1967) reasons any differences associated with the degree of bilingualism are not noted due to the constant effort required in switching languages.

Lambert, Havelka, and Gardner (1959) administered rating scales, fluency tests, flexibility measures, and linguistic dominance tests to a group of bilingual subjects to measure the degree of bilingualism present. They found these measures ". . were intercorrelated and could be interpreted as measuring a single factor." Thus, it would appear all of these tests tended to measure the presence and/or degree of bilingualism.

In 1969 Cooper designed a study to determine if the degree of bilingual dominance could be predicted by a word frequency estimation task. The subjects were asked to rate seventy-five common Spanish and English words, read by the examiner, in terms of frequency with which they heard or said the word. Fifteen words were chosen to represent each of the five domains of social interaction: family, education, religion, work, and neighborhood. The criterion variables used were: 
the scores from the English Repertoire Range Test (Cooper and Greenfield, 1969), self ratings of language used at home, self ratings of speaking skill, word naming, and accentedness. Cooper and Greenfield (1969) state the results of this study show that degrees of bilingualism in different social interaction areas can be measured by using a word frequency estimation task. Since bilinguals may. use one language at home and another at school, it is important to be able to measure their linguistic proficiency in a variety of different social interactions. Only by having a complete and accurate picture of the bilingual MexicanAmerican child's language ability can effective educational programs be developed and maintained.

\section{TESTSOF LANGUAGE}

To obtain information regarding the linguistic functioning of bilingual Mexican-American children from low socioeconomic backgrounds in Texas, Carrow (1957) recorded three minute samples of their language. She then compared their speaking vocabulary, index of subordination, verbal output, clause length, complexity of sentence structure, number and type of grammatical errors with those of English speaking monolingual Anglo-American children from low socioeconomic backgrounds in Texas. Although she found monolingual children to have a statistically better speaking and hearing vocabulary than bilingual children, there were no significant differences between the children in verbal output, clause length, degree of subordination, and complexity of sentence structure. In another study conducted in 1971 Carrow found MexicanAmerican children to be significantly delayed in either or both languages 
in the specific areas of plurals, pronouns, negatives, comprehension of tense markers (with the exception of present progressive), adjectives, and prepositions. She emphasizes that this may not be true of individuals within this group of low socioeconomic status children or of Mexican-American children from other socioeconomic levels or geographic areas outside of Texas. Thus, it would appear necessary to study Mexican-American children from other socioeconomic levels and geographic areas before drawing any conclusions about the language of these children. Since Carrow classified only 30 per cent of the children studied as bilingual, she believes inferences regarding bilingualism cannot be justified from these data. .

Hickey (1972) administered the Peabody Picture Vocabulary Test (Dunn, 1959) and the Draw-A-Man Test (Goodenough, 1926) to MexicanAmerican Headstart children and Anglo-American Headstart children in order to obtain information relative to the intellectual and verbal abilities of these two groups of children. He discovered when the stimulus word on the Peabody Picture Vocabulary Test was a "verbal noun" ending with "ing," e.g., hitting, ringing, climbing, pulling, et cetera, the bilingual child failed to identify correctly the appropriate matching picture. This was the only clear statistical difference between the two groups of scores. It was assumed the reason for this error was due to the difference in the grammatical structure of the English and Spanish languages. Hickey then modified the Peabody Picture Vocabulary Test by omitting the "verbal nouns," and readministered it to both groups of children. On the modified version of the Peabody Picture Vocabulary Test there was no clear statistical difference 
between the scores of either group of children. The interinstrument correlation between the Draw-A-Man Test and the standardized Peabody Picture Vocabulary Test was .81 for the Anglo-American group and .23 for the Mexican-American group; with the modified Peabody Picture Vocabulary Test it was .76 for the Anglo-American group and .64 for the Mexican-American group.

Based on the studies listed above, one might conclude there is a paucity of language tests available to assess the linguistic competence of Mexican-American children. In the past, investigations have relied too heavily on tests of intelligence in order to determine the level of language functioning of these children (Carrow, 1971).

A serious problem in measuring intellectual abilities of MexicanAmerican children is that of bilingualism and its effect on test scores (Sanchez, 1934; Granville, 1953; and Sattler, 1974). One hundred Mexican-American children were tested by Sheldon (1924) in Colorado with the Stanford-Binet and the Cole-Vincent Group Intelligence Test for School Entrants (1924), a test which aims to classify children by mental age. Sheldon had the Cole-Vincent translated into Spanish and administered by the teachers; he found a high correlation between the scores obtained on the two tests. The median I.Q. obtained by the Mexican-American children was 85 . The following questions were raised by Sanchez (1934) in regard to the validity of Sheldon's research:

1. What assurance is there the I.Q.'s obtained from the translated test were not comparable to the norms obtained on the English test?

2. Why should the I.Q.'s be raised by this procedure? 
3. Was the revised test the same test as the original in terms of difficulty, suitability, validity, reality, et cetera?

In 1928 Garth found the median I.Q. of one thousand Spanish speaking children tested from Texas, Colorado, and New Mexico to be 78; 50 per cent of these fourth grade children had an I.Q. score of 71.8 or less. According to this test 50 per cent of the Spanish speaking children represented could be considered to be borderline cases of mental retardation. Garth's study appears to be supported on the surface by the Sanchez (1934) study. Sanchez tested Spanish speaking MexicanAmerican children and found the median I.Q. of second grade children in a New Mexico grade school to be 75 . These children were given remedial instruction in language and language arts for a little more than two years. When retested at the end of this instruction, these MexicanAmerican children obtained a median score of 100 , which is in the normal range. Thus, it would appear the removal of the language handicap is necessary in order to evaluate properly Mexican-American children. Anastasi and Cordova (1953) believe it is not the bilingualism but the manner in which the two languages are learned which determines whether or not bilingualism constitutes a handicap. In Darcy's (1953) review of the literature few investigators were found who supported the contention that bilingualism had a favorable effect on the measurement of intelligence. The majority of researchers appear to believe bilinguals suffer from a language handicap when measured by verbal tests of I.Q. In an effort to determine the effect of bilingualism on verbal and nonverbal tests of intelligence Granville (1953) examined the literature and found an increase in the knowledge and use of English is 
associated with an increase in mental age.

Thus, it is not surprising that after review of the literature Keston and Jimenez (1954) concluded the Mexican-American population is generally retarded in intelligence. While there is little agreement as to the cause or causes of the "supposed retardation," there is general agreement as to the unfairness of measuring bilinguals with tests standardized on an English speaking population. As early as 1934, Sanchez stated,". . a test is valid only to the extent that the items of the test are as common to each child tested as they were to the children upon whom the norms were based." Bilingual Mexican-American children, however, were still being labeled mentally retarded as late as 1965. In a publication prepared by the National Council of Teachers of English (1965) the present retardation crisis of that period was blamed on the lack of educational opportunities available to provide for the language needs of the "deprived child."

Sattler (1974) states there are many hazards in translating test content or test instructions from English into Spanish,".. . translation of a test makes it a hybrid which belongs to neither culture." Since the language content of the tests are inappropriate, the group is not represented in norms and the testing situation is atypical; hence, it may be concluded these tests fail to measure adequately the intelligence of Mexican-American children (Ramirez and Gonzales, 1971). If such tests must be used, then one should observe the caution of Sanchez (1934):

An I.Q. is valuable only in relation to the hereditary, cultural, social, and educational background of the child 
and the way in which that past history can be utilized and improved in making the child the best possible person he is capable of being.

\section{SUMMARY}

A review of the literature in this field reveals a tremendous need for the development of language tests which recognize both cultures of the Mexican-American child, tests that give a valid and reliable indication of the linguistic abilities of this child in both Spanish and Finglish. Only through recognizing that Mexican-American children are a unique combination of both cultures can we hope to solve the educational problem of these children (Holland, 1960). 
CHAPTER III

\section{METHODS AND PROCEDURES}

\section{SUBJECTS}

Two groups of preschool children were randomly chosen. The experimental group was composed of twenty-one bilingual MexicanAmerican children from the Title $1 M$ Sumer School at Nellie Miur Grade School in Woodburn, Oregon. The control group was composed of twentyone monolingual Anglo-American children from the Barlow Child Development Center in Barlow, Oregon, the Woodburn Child Development Center in Woodburn, Oregon, and the Benedictine Child Development Center in Mt. Ange 1, Oregon.

\section{VARIABLES}

Age

Children included in the investigation ranged from 4.0 to 5.11 years of age. The mean chronological age for the control group was 4.90 and for the experimental group 4.98 with standard deviations of .619 and .58 respectively.' Thus, there was an age difference of less than one month between the two groups.

$\underline{\text { Sex }}$

There was no attempt to control the sex ratio of the children in either group. 
Intelligence.

An estimation of the child's mental ability was provided by the classroom teacher, based on the child's performance in class; and any child suspected of being depressed intellectually was eliminated from this investigation.

\section{Socioeconomic Status}

Carrow (1968), Palmer and Gaffney (1972), Bourgeois (1974), and Toronto (1974) emphasize the importance of controlling socioeconomic status. Thus, all these children came from programs in rural areas which accepted only children from low socioeconomic groups. See Appendix A for criteria used in selecting the Mexican-American children for the Title $1 \mathrm{M}$ Summer School, and Appendix B for criteria used in selecting the Anglo-American children.

\section{Auditory Acuity}

Before either language test was administered, each child passed a bilateral puretone audiometric sweep scan at $25 \mathrm{~dB}$ (ISO) for the speech frequencies of $500,1 \mathrm{~K}, 2 \mathrm{~K}$, and $4 \mathrm{~K} \mathrm{~Hz}$. All subjects were screened by this examiner in a quiet room at their school, using a portable Beltone Audiometer (Model 10-C) with Auraldone headphones (Model AR100).

\section{INSTRUMENTS}

\section{The Mexican-American Inventory of Receptive Abilities (MIRA,}

which means "look" in Spanish) was developed in 1974 by Nelson-Burgess and Meyerson. This is a receptive test which primarily purports to measure bilingual dominance configuration (the language in which a 
child operates most easily) and to assess the child's vocabulary skills in both English and Spanish (see Appendix C for a copy of the test form). For this test, a list of lexical items was compiled which the authors believed represented the language spoken in the San Joaquin Valley of California. These words were obtained through home interviews with local bilingual families with small children. Such interviews led to the addition of many regional lexical items, for example, carro for automovil (car) and trocke for camion (truck), which are not part of standard Spanish. Consultations with bilingual administrators led to the addition of English words which bilingual children should be expected to know when entering kindergarten.

This test is composed of Spanish and English words; there are four simple colored pictures of different objects on each page, making a total of twenty-six pages, thirteen for the English tegt and thirteen for the Spanish test. While a total of fifty-two Spanish and fifty-two Fnglish words is used in this test, a quick screening can be done in both languages, using only twenty-six items. The examiner asks the child to point to one item on each page, and marks the response either correct or incorrect on a record form.

A major problem encountered in utilizing the MIRA was the unidentical word lists in Spanish and English. Hence, this investigator found it necessary to develop identical word lists through translation; and translated the Spanish word Iist into English and then submitted it for approval to Robert L. Casteel (1975), an authority in the area of normal language development. He stated four- and five-year-old children should be able to identify correctly the following words: mama, cat, 
car, mouth, chair, ball, his, flower, eye, tree, bed, glass, and yellow. To translate the English words into Spanish a Pilot study was done with nine six-year-old Mexican-American children, four boys and five girls. The nine children each passed the same bilateral puretone audiometric sweep scan at $25 \mathrm{~dB}$ (ISO) as the subjects. Each child was then shown the English pictures and asked to name them in Spanish. The phrases, "Que es eso?" ("What is it?"), "Que esta haciendo?" ("What is she doing?"), or for number two, "Como esta? Esta triste o esta ?" ("How is she? Is she sad or ___ ?") The response given most often by the children in the Pilot study was then used on the Spanish portion of the test (see Appendix D). This revised word list, together with the original MIRA list, was used in the present investigation. Hereafter, the original word list will be referred to as Part I and the revised word list as Part II, for both Spanish and English versions of the MIRA.

While no attempt was made to generalize this test to other Mexican-American populations, the authors are convinced the underlying concept development of the test is universal and that it can be applied to other groups of Mexican-American children in the United States. At the present time there are no norms for this test in English or Spanish and it is not commercially available (see Appendix E for the present investigator's modified MIRA test form).

The Peabody Picture Vocabulary Test--PPVT (Dunn, 1959) is a receptive picture vocabulary test composed of 150 plates or pages, each page containing four different simple black and whilte pictures. The examiner asks the child to point to one item on each page and marks the 
response either correct or incorrect on a record form. To establish basal the child must answer correctly eight items in a row; the ceiling is reached when the child misses six out of eight consecutively presented items. This test was administered to each child until the ceiling had been reached (see Appendix F for a copy of the test form).

\section{PROCEDURES}

The experimental group was chosen by random sample selection and the control group was matched within two months of the chronological age of each child in the experimental group.

A parental permission slip was sent home with each prospective subject (see Appendices $G$ and H). If the slip was not returned, the examiner visited the home and secured written permission.

Before the testing began, the examiner spent time in the classroom talking, listening, and playing with the children. During the testing session, each child was alone in a room with the examiner. The examiner determined bilingualism by having the child respond to the items listed in Chapter I under the operational definitions for bilingualism.

\section{TEST ADMINISTRATION}

The MIRA, both English and Spanish versions, was administered to the Mexican-American children. Since Carrow (1973) believes the test should first be administered in the language which is dominant for the child, the test was first administered in the language the classroom teacher believed to be dominant for each child. On a random basis Parts 
I and II of the dominant language test were first administered; then

Parts I and II of the nondominant language test were administered.

After both parts of the Spanish and English tests were given, the PPVT

was administered"until a ceiling was reached. Each Anglo-American

child was given both parts of the English portion of the MIRA and then the PPVT until a ceiling was established. The two tests were administered as follows:

1. The MIRA was presented to each child; both verbal and visual stimuli were used. The subject was asked to point to the picture named by the investigator (see Appendix $\mathrm{E}$ for specific stimuli).

2. The PPVT was administered according to standard instructions provided by Dunn (1959). (See Appendix F for specific stimali.)

\section{DATA ANALYSIS}

Comparisons in vocabulary performance on the MIRA and PPVT were made between the experimental and control groups. Mean scores and standard deviations were determined for the performance of each group, and the differences between the means of the two groups were analyzed, utilizing the t-test. 
CHAPTER IV

RESULTS AND DISCUSSION OF RESULTS

\section{RESULTS}

This study sought to investigate the vocabulary abilities of four- and five-year-old Mexican-American bilingual children, and was designed to compare the vocabulaxy performance of two groups of children of the same age: bilingual Mexican-Americans and monolingual Anglo-Amercicans. Comparison of the vocabulary abilities of these children was accomplished by administering a modified version of the Mexican-American Inventory of Receptive Abilities--MIRA (Nelson-Burgess and Meyerson, 1975), and the Peabody Picture Vocabulary Test--PPVT (Dunn, 1959), in order to test the following research questions:

1. Do Mexican-American children perform the same on the Spanish portion of the modified MIRA as on the English portion?

2. Do Mexican-American children perform the same on the English portion of the modified MIRA as do the Anglo-American children?

3. Do Mexican-American children perform the same on the Spanish portion of the modified MIRA as AngloAmerican children do on the English portion of the modified MIRA?

4. Do Mexican-American children perform the same on the English portion of the modified MIRA as they do on the PPVT?

5. Do Mexican-American children perform the same on the Spanish portion of the modified MIRA as they do on the PPVT? 
6. Do Mexican-American children perform the same on the PPVT as do the Anglo-American children?

Mexican-American Inventory of Receptive Abilities

As previously noted, while both the English Parts I and II and the Spanish Parts I and II were administered to the experimental group of Mexican-American children, only the English Parts I and II were administered to the control group of Anglo-American children.

Comparison of Performance Between Groups. Fixamination of Table I reveals that a perfect score on the MIRA totals 26 points; while the experimental group obtained a mean raw score of 24 points, the control group obtained a mean raw score of 25 points. Thus, with only a one point difference, it can be noted by visual inspection a significant difference does not exist; hence, no further statistical analysis was made.

Comparison of Performance Within Groups. Performance of the experimental subjects on the Spanish portion of the MIRA was compared with their performance on the English portion. Reference to Table I once again reveals, that out of a possible 26 points, they obtained a mean raw score of 24 points on each portion of the MIRA. Additionally, a comparison of the experimental group's mean raw score on each of the four parts was made; they scored 12 points on each part out of a possible 13.

The control group obtained a mean raw score of 25 points out of a possible 26 on the English portion of the MIRA; they scored 13 points on Part I and 12 points on Part II. Therefore, as with the between group analysis, no further statistical treatment of data was calculated 
TABIE I

TEST RESULTS FROM THE MIRA SHOWING MEAN RAW SCORES

FOR BOTH THE EXPERIMENTAL AND CONTROL GROUPS

\begin{tabular}{|c|c|c|}
\hline \multirow{2}{*}{ MIRA Test } & \multicolumn{2}{|c|}{ Mean Raw Score } \\
\hline & $\begin{array}{c}\text { Experimental } \\
\text { Group }\end{array}$ & $\begin{array}{l}\text { Control } \\
\text { Group }\end{array}$ \\
\hline $\begin{array}{l}\text { English portion: } \\
\text { Part I } \\
\text { Part II } \\
\text { Total score }\end{array}$ & $\begin{array}{l}12 \\
12 \\
24\end{array}$ & $\begin{array}{l}13 \\
12 \\
25\end{array}$ \\
\hline $\begin{array}{l}\text { Spanish portion: } \\
\text { Part I } \\
\text { Part II } \\
\text { Total score }\end{array}$ & $\begin{array}{l}12 \\
12 \\
24\end{array}$ & $\begin{array}{c}\text { Not } \\
\text { administered }\end{array}$ \\
\hline
\end{tabular}

because of minor differences in scores.

Peabody Picture Vocabulary Test

Range of Raw Scores for Experimental and Control Groups. Indi-

vidual test scores obtained on the PPVI by each subject are illustrated in Table II. Here it can be seen there was a wide variation in the raw scores achieved on the PFVT by the experimental group, ranging from a low of 10 to a high of 57 . In contrast, there was less variation within the control group; they ranged from a low of 26 to a high of 63 . Hence, it would appear the experimental group was more heterogeneous 
TABLE II

TEST RESULTS ON THE PPVT SHOWING INDIVIDUAL RAW SCORES FOR BOTH THE EXPERTMENTAL AND CONTROL SUBJECTS

\begin{tabular}{|c|c|c|c|c|c|}
\hline \multicolumn{3}{|c|}{ Mexican-Americans } & \multicolumn{3}{|c|}{ Anglo-Americans } \\
\hline Subjects & C. A.- & Raw score & Subjects & C. A. & Raw Score \\
\hline 1 & 4.2 & 17 & 1 & 4.0 & 51 \\
\hline 2 & 4.2 & 39 & 2 & 4.0 & 32 \\
\hline 3 & 4.4 & 11 & 3 & 4.3 & 52 \\
\hline 4 & 4.5 & 20 & 4 & 4.4 & 26 \\
\hline 5 & 4.7 & 13 & 5 & 4.5 & 57 \\
\hline 6 & 4.7 & 36 & 6 & 4.5 & 57 \\
\hline 7 & 4.8 & 29 & 7 & 4.7 & 57 \\
\hline 8 & 4.10 & 17 & 8 & 4.8 & 51 \\
\hline 9 & 4.11 & 13 & 9 & 4.9 & 51 \\
\hline 10 & 5.0 & 21 & 10 & 4.10 & 55 \\
\hline 11 & 5.0 & 55 & 11 & 4.11 & 42 \\
\hline 12 & 5.0 & 13 & 12 & 5.0 & 57 \\
\hline 13 & 5.2 & 10 & 13 & 5.3 & 37 \\
\hline 14 & 5.4 & 21 & 14 & 5.3 & 50 \\
\hline 15 & 5.5 & 20 & 15 & 5.4 & 54 \\
\hline 16 & 5.5 & 12 & 16 & 5.4 & 63 \\
\hline 17 & 5.7 & 33 & 17 & 5.6 & 52 \\
\hline 18 & 5.7 & 53 & 18 & 5.7 & 44 \\
\hline 19 & 5.8 & 57 & 19 & 5.8 & 56 \\
\hline 20 & 5.9 & 37 & 20 & 5.9 & 63 \\
\hline 21 & 5.11 & 56 & 21 & 5.11 & 62 \\
\hline
\end{tabular}


than the control group.

Comparison in Performance Between Groups. Means, standard deviations, and t-test scores for both the experimental and control groups are found in Table III. It is observed that while the control group obtained a mean ceiling of 63.25 , the experimental group's ceiling was 42.38. The experimental group's mean raw score was 27.76 with a standard deviation of 16.25; the control group obtained a mean raw score of 50.90 with a standard deviation of 9.79. A t-test comparison

\section{TABLE III}

COMPARISON OF RAW SCORES ON PPVT SHOWING MEANS, STANDARD DEVIATIONS, AND t-TEST RESULTS FOR BOTH THE EXPERIMENTAL AND CONTROL GROUPS

\begin{tabular}{lccc}
\hline Test Group & $\begin{array}{c}\text { Mean } \\
\text { Baw Score }\end{array}$ & $\begin{array}{c}\text { Standard } \\
\text { Deviation }\end{array}$ & t-Score \\
\hline Experimental & 27.76 & 16.25 & $5.590 *$ \\
Control & 50.90 & 9.79 & \\
\hline
\end{tabular}

$$
\begin{aligned}
* t & <.001 \\
N & =42
\end{aligned}
$$

between the means of the raw scores for the control and experimental groups revealed a statistically significant difference. The resulting t-value of 5.590 was significant with $p<001$, utilizing a two-tailed test. Thus, the experimental group knew significantly less receptive pictorial English vocabulary items than the control group.

Analyses of Data to Determine Possible Marked Differences Between Groups. Although such analyses of data were not a part of the present 
study, this investigator sought to determine possible reasons for the marked difference between the groups on the PPVT. Hickey (1972) proposed the theory that the presence of "ing" words lowered the scores obtained on the PPVI by Mexican-American children. He believed MexicanAmerican children were unable to respond correctly to the "ing" words due to differences in the Spanish and English language structure. Hence, analyses of "ing" words and "non-ing" words were made; the results are illustrated in Tables IV and $\mathrm{V}$.

The number of "ing" words within the mean ceiling of 42 for the experimental group and 64 for the control group were counted. There were 8 "ing" words within the first 42 items on the PPVT; the experimental group obtained a mean of 3.71 with a standard deviation of 2.513. There were 12 "ing" words within the first 64 items on the PPVT; the control group obtained a mean of 11.33 words with a standard deviation of 2.133. Using a t-test, the mean raw score of the experimental group was compared to that of the control group; a t-value of 7.88 resulted, with $\mathrm{p}<.001$ (Table IV).

The number of "non-ing" words within the mean ceiling for each group were counted and the number of correct responses noted. There were 42 "non-ing" words for the experimental group, which obtained a mean raw score of 20.57 with a standard deviation of 8.65 . The control group, on the other hand, encountered 52 "non-ing" words and obtained a mean raw score of 40.33 with a standard deviation of 7.64 . The resulting t-value of 7.84 was statistically significant with a $p<001$ (see Table v). 
TABLE IV

COMPARISON OF CORRECT "ING" WORDS ON PPVT SHOWING MEANS, STANDARD DEVIATIONS, AND t-TEST RESUTTS FOR BOTH THE EXXPERIMENTAI AND CONTROL GROUPS

\begin{tabular}{lccc}
\hline Test Group & $\begin{array}{c}\text { Mean } \\
\text { Raw Score }\end{array}$ & $\begin{array}{c}\text { Standard } \\
\text { Deviation }\end{array}$ & t-Score \\
Experimental & 3.71 & 2.51 & $7.88^{*}$ \\
Control & 9.38 & 2.13 & \\
\hline & & & \\
$* t<.001$ & & \\
$N=42$
\end{tabular}

TABLE V

COMPARISON OF CORRECT "WNON-ING" WORDS ON PPVT SHOWING MEANS, STANDARD DEVIATIONS, AND t-TEST RESUTTS FOR BOTH THE EXPERTMENTAL AND CONTROL GROUPS

\begin{tabular}{lccc}
\hline Test Group & $\begin{array}{c}\text { Mean } \\
\text { Raw Score }\end{array}$ & $\begin{array}{r}\text { Standard } \\
\text { Deviation }\end{array}$ & t-Score \\
\hline Experimental & 20.57 & 8.65 & $7.84^{*}$ \\
Control & 40.33 & 7.64 & \\
\hline
\end{tabular}

$$
\begin{gathered}
* t<.001 \\
N=42
\end{gathered}
$$




\section{DISCUSSION}

Carrow (1971) believes language development is closely related to socioeconomic status and intelligence; hence, an effort to control both was made in the present investigation. The teachers were asked to eliminate any child thought to be intellectually deficient; socioeconomic status was controlled by using only children from families of low socioeconomic status (see Appendices $A$ and $B$ ).

As noted previously, this investigator sought to answer six essential questions relative to the vocabulary performance of four- and five-year-old bilingual Mexican-American children when compared to Anglo-American children of the same age and relatively the same socioeconomic status.

Performance of Mexican-American and Anglo-American Children on the MIRA

As to the first question, it was found that Mexican-American children do perform the same on the Spanish and Rnglish portions of the modified MIRA. It has been noted that a comparison between the mean scores achieved on both the English and Spanish portions of the MIRA did not reveal a difference (Table I). In fact, the score was the same not only on both portions of this test but also on each of the four parts. These findings would seem to indicate that for this particular group both of the languages and each part within the two languages were equally difficult. Since this test did not make a distinction between the performance of the experimental group on the English and Spanish portions of the test, these children would seem to have equal ability 
in this area.

As to the second question, as noted in Table I, Mexican-American children did perform the same on the English portion of the modified MIRA as Anglo=American children. A comparison between mean raw scores achieved on the English portion of the modified MIRA did not reveal a difference.

In answer to the third question, Mexican-American children do perform the same on the Spanish portion of the modified MIRA as AngloAmerican children do on the Fnglish portion of this test. A comparison between the mean raw scores achieved on the Spanish portion of the modified MIRA by the experimental group with that of the control group on the English portion of the modified MIRA does not reflect a difference.

The findings of this investigation are not compatible with those of the Carrow (1957) study. She found monolingual Anglo-American children from low socioeconomic backgrounds to have statistically better speaking and hearing vocabularies than bilingual Mexican-American children from the same socioeconomic background. One might conjecture that a possible reason for the difference between the Carrow (1957) study and this investigation may be due to the type of instrument administered. While Carrow recorded three-minute samples of the MexicanAmerican child's language and evaluated it, the modified MIRA is a pictorial receptive vocabulary test. Hence, in the Carrow investigation it was possible to do a more indepth evaluation of the MexicanAmerican child's language abilities than with the modified MIRA. The authors of the unmodified version of the MIRA failed to 
report statistical data relative to the use of this test with a Mexican-American population in the San Joaquin Valley of California. Since the experimental group, as well as the control group, received an almost perfect mean raw score on the modified MIRA used in the present investigation, one wonders if there is such a vast difference between Mexican-American children in California and Oregon. Thus, this investigator tends to doubt the validity of this test as a screening instrument to be used with four- and five-year-old Mexican-American children in Oregon. Possibly, it might be used with younger children; however, it would have to be tested empirically before one could reason to this conclusion with confidence.

Relative to the fourth and fifth questions proposed by this investigation, it was shown that Mexican-American children do perform the same on the English and Spanish portions of the modified MIRA. They do not perform the same, however, on the modified MIRA as they do on the PPVT. One might conjecture that the difference between the Mexican-American children's performance on these tests is due to the words on the MIRA being primarily names of objects, whereas the words on the PPVT include more abstract concepts. Since it is apparent, by visual inspection, the Mexican-American children did well on the modified MIRA and poorly on the PPVT, no statistical treatment was necessary. This investigator suggests a reason for the difference in performance may be that the modified MIRA is not a sufficiently sensitive enough instrument to determine if any receptive pictorial vocabulary weakness exists. Due to its apparent lack of discriminative ability, one wonders if it might not allow too many children in need of special 
assistance in linguistic skill to go undetected.

Performance of

Mexican-American and Anglo-American Children on the PPVT

As to the sixth question, it was found Mexican-American children do not perform the same on the PPVT as Anglo-American children. While the mean for the experimental group was 27 , the lowest score obtained by an Anglo-American child was 26. A closer examination of these scores reveals that as the Mexican-American children's age increased so did their scores. There was a difference in the mean scores between the two groups of four- and five-year-old children of 26.61 and 21.47 respectively. Thus, one wonders if this might indicate the beginning of an upward trend in scores, and, if so, how far upward in terms of age would this trend continue.

The experimental group achieved a wide variation in their individual raw scores (Table II). Hence, the findings reported in this study tend to support those of Carrow (1971) in the respect that Mexican-American children in Oregon, as in Texas, would appear to be a/ heterogeneous group.

This investigation, as in the Hickey (1972) study, showed the control group scoring significantly higher on the PPVT than the experimental group (Table III). When Hickey analyzed his data be found the only really significant difference between the two groups was their performance on "ing" words. Thus, he eliminated the "ing" words from his modified PPVI and readministered the test. While eliminating the "ing" words in the Hickey study removed the statistical difference between the two groups, it did not produce a similar result in this 
investigation (Table IV).

Since removing the responses of the "ing" words did not change the results, the "non-ing" words were isolated and examined. Neither removing the "ing" words nor the "non-ing" words from the PPVT affected the fact that the control group scored significantly higher than the experimental group on this test (see Table V).

Results of this test, which show the experimental group scoring significantly lower than the control group, tend to be supported by other investigations in the literature. Sheldon (1924) and Garth (1928) found the Mexican-American children they tested to be mentally retarded; the conclusion of the Keston (1954) review of the literature was that the Mexican-American population was generally retarded in intelligence. Before any further conclusions can be made, however, one must consider the cautions offered by the following investigators: 1) Sanchez (1934) stated, "A test is valid only to the extent that the items of the test are as common to each child tested as they were to the children upon whom the norms were based"; 2) another conclusion of Keston's (1954) review of the literature was the unfairness of testing bilinguals with tests standardized on an English speaking population; and 3) Ramirez and Gonzales (1971) stress that the language content of the tests must be appropriate, the groups must be represented in norms, and the testing situation must be typical to adequately measure the intelligence of Mexican-American children.

While the PPVT is sometimes used to measure the language age or even mental age of a child, it cannot be used to test Mexican-American children in this manner with any degree of confidence. Therefore, this 
investigator strongly recomends the PPVT be used with Mexican-American children only as an instrument to aid in identifying any receptive pictorial vocabulary concepts that are weak or absent, in order to develop teaching strategies. 


\section{CHAPTER V}

\section{SUMMARY AND IMPLICATIONS}

\section{SUMMARY}

This study sought to investigate the Spanish and English receptive pictorial vocabulary of four- and five-year-old bilingual MexicanAmerican children. The performance of bilingual Mexican-American children on the Mexican-American Inventory of Receptive Abilities--MIRA (Nelson-Burgess and Meyerson, 1975) and the Peabody Picture Vocabulary Test--PPVT (Dunn, 1959) was compared to that of monolingual AngloAmerican children of the same relative age range and socioeconomic level.

Forty-two subjects were included in this study. Twenty-one bilingual Mexican-American children between the ages of 4.0 years and 5.11 years were randomly selected from the Title $1 \mathrm{M}$ Sumer School at Nellie Miur Grade School in Woodburn, Oregon. The control group was composed of twenty-one monolingual Anglo-American children from the Barlow Child Development Center in Barlow, Oregon, the Woodburn Child Development Center in Woodburn, Oregon, and the Benedictine Child Development Center in Mt. Angel, Oregon. All these centers had the same socioeconomic qualification for accepting children, were geographically close to one another, and were located in rural areas. Children in the control group were matched within two months of the chronological age of the experimental group. Both the control and experimental subjects 
were screened for hearing acuity and the children's teachers were asked to eliminate any child they suspected might be intellectually deficient.

Since both groups of children achieved an almost perfect score on the modified MIRA, it is believed this test was unable to measure accurately the receptive pictorial vocabulary performance of these children. Furthermore, the results of this test did not illustrate any distinction between the vocabulary performance of the experimental group in English and Spanish. Hence, all findings relative to this test were statistically nonsignificant.

The authors reported the MIRA was currently being used as a screening instrument in the San Joaquin Valley of California. Unfortunately, based on the findings of this investigation, the modified MIRA cannot be used with confidence as a screening instrument for four- and five-year-old Mexican-American children in the Woodburn area of Oregon. Since the only difference between the MIRA and the modified MIRA is that the modified MIRA was extended by translating the word lists into the other language, one might wonder about the effectiveness of the MIRA as a screening instrument--unless, of course, there is a vast difference between Mexican-American children living in Oregon and those living in California. Perhaps the MIRA could be used with younger children; however, it would have to be tested empirically before one could reach this conclusion with confidence.

The raw scores for both the experimental and control groups on the PPVT, however, were statistically significant. Results revealed a significantly lower performance in the areas of receptive pictorial English vocabulary abilities of bilingual Mexican-American children 
when compared with monolingual Anglo-American children. A wide variation was found in the individual scores of the experimental group. Thus, a secondary finding in this study was Mexican-American children in Oregon, as in Texas (Carrow, 1971), are a heterogeneous group, and there is a wide range of abilities present in the receptive English pictorial vocabulary skills of these children.

Hickey (1972) proposed the theory that the difference between the raw scores of the two groups was due to the Mexican-American children's inability to respond correctly to the "ing" words on the PPVT; hence, their responses as a group to such words were examined. It was found that neither eliminating the "ing" words nor the "non-ing" words affected the results of this investigation.

\section{IMPLICATIONS}

The modified MIRA does not appear to be able to evaluate accurately the vocabulary level of bilingual four- and five-year-old Mexican-American children in 0regon. In fact, the modified MIRA does not provide an indication of where to begin language management for these four- and five-year-old children. In order for the MIRA to become a useful tool in language evaluation and management of bilingual four- and five-year-old Mexican-American children in Oregon, it would be necessary to expand and increase the difficulty of this test so that it would provide more of a challenge to this specific population of children. Perhaps the MIRA might be used with younger children; however, this conclusion would need to be validated. 
While the PPVT cannot be used as an instrument to evaluate the vocabulary abilities of Mexican-American children, it can be used to indicate areas or concepts in English which are weak or absent in their receptive pictorial vocabulary. These areas then can be strengthened by direct language intervention. Since the experimental group's score on the PPVT increased with age, one might speculate this could be part of an upward trend. Further investigation, however, would be necessary to determine if these scores reflect any indication of an upward trend in correct responses. If there is a trend, it would be important to determine not only when it begins, where it peaks, and how long it lasts, but also when is the best possible time to initiate a language management program. 
B I $\underline{B} \underline{\mathrm{L}} \underline{\mathbf{O}} \underline{\mathbf{G}} \underline{\mathrm{R}} \underline{\mathrm{A}} \underline{\mathrm{P}} \underline{\mathrm{H}} \underline{\mathrm{Y}}$ 


\title{
BIBLIOGRAPHY
}

\author{
SOURCES CITED
}

Anastasi, A., and Cordova, F., Some effects of bilingualism upon the intelligence performance of Puerto Rican children in New York City. J. Educational Psychol., 44, 1-19 (1953).

Baltaxe, C., Language disabilities in bilingual children. Paper presented at the American Speech and Hearing Association Convention, Las Vegas (November 1974).

Bloomfield, L., Language. New York: Holt (1933).

Bourgeois, P., A speech and language program for inner-city children. Paper presented at the American Speech and Hearing Association Conrention, Las Vegas (November 1974).

Carrow, Elizabeth, Linguistic functioning of bilingual and monolingual children. J. Speech Hearing Dis., 22, 371-380 (1957).

Carrow, Elizabeth, The development of auditory comprehension of language structure in children. J. Speech Hearing Dis., 33, 99-111 (1968).

Carrow, Elizabeth, Comprehension of English and Spanish by pre-school Mexican-American children. Modern Language J., 55, 299-306 (1971).

Casey, Maureen, A comparative study of language comprehension measures of Spanish-American and Anglo-American kindergarten children. Unpublished master's thesis, Washington State University (1974).

Castee1, Robert, Conference held on July 2, 1975.

Cooper, Robert, Two contextualized measures of degree of bilingualism. Modern Language J., 53, 172-182 (1969).

Cooper, Robert, and Greenfield, Lawrence, Word frequency estimation as a measure of degree of bilingualism. Modern Language J., 53, 163-166 (1969).

Corbin, Richard, and Crosby, Muriel (Eds.), Language Program for the Disadvantaged. Urbana: National Council of Teachers of English (1965). 
Darcy, N., A review of literature on the effects of bilingualism upon the measurement of intelligence. Pedagogical Seminary, 82, 21-57 (1953).

Dunn, Iloyd M., Peabody Picture Vocabulary Test. Minneapolis: American Guidance Service (1959).

Edelman, Martin, The contextualization of school-children's bilingualism. Modern Language J., 53, 179-182 (1969).

Ervin, Susan, Learning and recall in bilinguals. American J. Psychol., $74,446-451$ (1961).

Ervin-Tripp, Susan, An analysis of the interaction of language, topic and listener. The Ethnography of Communication, American Anthropologist, 3, 86-102 (1964).

Fishman, Joshua, Sociolinguistic perspective on the study of bilingualism. Linguistics, 39, 21-49 (1968).

Garth, T. R., The intelligence of Mexican-American children. School and Society, XXVII, 791-794 (1928).

Gonzales, Josue, Growth pains in bilingual bicultural education since Tucson, 1966. Paper presented at convention of National Education Association and National Education Task Force de la Raza, Washington, D.C. (1973).

Granville, B. Johnson, Jx., Bilingualism as measured by a reactiontime technique and the relationship between a language and a nonlanguage intelligence quotient. J. Genetic Psychol., 32, 3-9 (1953).

Gumperz, John J., Linguistic and social interaction in two communities. American Anthropologist, LXVI, 137-153 (1964).

Guralnik, David, Webster's New World Dictionary of the American Language. Cleveland: The World Publishing Company (1968).

Haugen, E., The Norwegian in America: A Study of Bilingual Behavior. Philadelphia: University of Pennsylvania (1953).

Hickey, Tom, Bilingualism and the measurement of intelligence and verbal learning abilities. Except. Child, 39, 24-28 (1972).

Holland, W., Language barrier as an educational problem of Spanish speaking children. Except. Child, 27, 42-50 (1960).

Kappelman, Murray, Kaplan, Eugene, and Genter, Robert, A study of learning disorders among disadvantaged children. J. Learning Disabilities, 2, 261-268 (1969). 
Keston, Morton, and Jimenez, Carmina, A study of the performance on Finglish and Spanish editions of the Stanford Binet Intelligence Test by Spanish-American children. J. Genetic Psychol., 85, 263-269 (1954).

Kolers, Paul A., Interlingual facilitation in short-term memory. J. Verbal Behavior, 5, 314-319 (1966).

Lambert, Wallace, Measurement of the linguistic dominance of bilinguals. J. Abnormal and Social Psychol., 50, 197-200 (1955).

Lambert, Wallace, Havelka, J., and Gardner, R., Linguistic manifestations of bilingualism. American J. Psychol., 72, 77-82 (1959).

Lewis, Hilda, and Lewis, Edward, Written language performance of 6 th grade children of low socioeconomic status from bilingual and from monolingual backgrounds. J. Experimental Education, 33, 237-242 (1965).

Mackey, W. F., The description of bilingualism. Canadian J. Linguistics, 7, 51-85 (1962).

Macnamara, John, Linguistic performance. J. Social Issues, 23, 58-77 (1967).

Miller, G. A., Galanter, E., and Pribram, K. H., Plans and the Structure of Behavior. New York: Holt (1960).

Nelson-Burgess, Shirley and Meyerson, Marion, MIRA: A concept in receptive language assessment of bilingual children. Language Speech and Hearing Services in the School, 6, 24-27 (1975).

Norman, R., and Mead, D., Spanish-American bilingualism and the Ammons and Ammons Full-Range Picture Vocabulary Test. J. Social Psychol., 51, 319-330 (1960).

Oregon Board of Education, Division of Compensatory Education, Salem, Oregon (1967).

Oregon Board of Education, Division of Compensatory Education, Salem, Oregon (1975).

Palmer, M., and Gaffney, P. D., Effects of administration of the WISC in Spanish and Finglish and relationship of social class to performance. Psychol. in School, 9, 61-74 (1972).

Penfield, W., and Roberts, L., Speech and Brain Mechanisms. Princeton: Princeton University Press (1959).

Preston, M. S., Inter-lingual interference in a bilingual version of the Stroop Color-Word Test. Doctoral dissertaion. Montreal: McGill University (1965). 
Ramirez, R. M., and Gonzalez, A., Mexican-Americans and Intelligence Testing: Racism in the Schools. Riverside: University of California (1971).

Rao, T., Development and use of directions test for measuring degree of bilingualism. J.Psychol. Research, 8, 114-119 (1964).

Sanchez, G. I., Bilingualism and mental measures. J. Applied Psychol., 18, 765-772 (1934).

Sanchez, G. I., Forgotten People: A Study of New Mexicans. Albuquerque: Calvin Horn Publishers, Inc. (1967).

Sattler, Jerome M., Assessment of Children's Intelligence. Philadelphia: W. B. Saunders Co. (1974).

Sepulveda, Betty, The language barrier and its effect on learning. Elementary English, 50, 209-217 (1973):

Sheldon, W. H., The intelligence of Mexican-American children. School and Society, XIX, 139-142 (1924).

Sherk, John, Dialect--The invisible barrier to progress in the language arts. In The Reading Bulletin. Rockleigh, N.J.: Allyn and Bacon, Inc. (1965).

Toronto, Allen, The effectiveness of language remediation in Spanish or English for language-deviant, Spanish speaking children. Paper presented at the American Speech and Hearing Association Convention, Las Vegas (November 1974).

Treisman, Anne M., The effects of redundancy and familiarity on translating and repeating back a foreign and a native language. British J. Psychol., 56, 369-379 (1965).

U.S. Department of Commerce, Bureau of the Census, Population Characteristics. Series T-20, No. 267 (July 1974).

U.S. Department of Commerce, Bureau of the Census, Educational Level. Series T-20, No. 274 (December 1974).

Wald, B., Bilingualism. Los Angeles: University of California (1973).

Weinreich, U., Languages in Contact: Findings and Problems. The Hague: Mouton $(1 \overline{963)}$. 
SOURCES CONSULTED BUT NOT CITED

Altus, G. T., WISC patterns of a selective sample of bilingual school children. J. Genetic Psychol., 83, 241-248 (1953).

Ammons, R. B., and Aguero, A., The Full-Range Picture Vocabulary Test: Results for a Spanish-American school population. J. Social Psychol., 32, 3-10 (1950).

Armendariz, Abe, and Armendariz, Ema, Directory of State Participation in Bilingual-Bicultural Education. Washington, D.C.: National Bilingual Bicultural Institute (1973).

Berney, Tom, and Cooper, Bobert, Semantic independence and degree of bilingualism in two communities. Moderm Language J., 53, 182-185 $(1969)$.

Carrow, Elizabeth, Auditory comprehension of English by monolingual and bilingual pre-school children. J. Speech Hearing Res., 15, 407412 (1972).

Carrow, Elizabeth, Test for Auditory Comprehension of Language. Texas: Urban Research Group Learning Concepts (1973).

Chandler, J., and Plakos, J., Spanish speaking pupils classified as educable mentally retarded. Integrated Education, 42, 51-54 (1969).

Cooper, Robert, and Greenfield, Lawrence, Language use in a bilingual community. Modern Language J., 53, 166-172 (1969).

Fhrlich, Alan, and Fhrlich, Roselin, Tests in Spanish and Other Languages, English as a Second Language, and Nonverbal Tests for Bilingual Programs. New York City: Bilingual Education Applied Research Unit (1974).

Brvin, Susan, Semantic shift in bilingualism. American J. Psychol., $74,233-241$ (1961).

Ervin, Susan, and Osgood, C. E., Second language learning and bilingualism. J. Abnormal and Social Psychol., 49, 139-146 (1954).

Kidd, A. H., The culture fair aspects of Cattell's test of G: Culture free. J. Genetic Psychol., 101, 343-362 (1962).

Killian, L. R., WISC, ITPA, and Bender-Visual-Motor Gestalt Test performance of Spanish-American kindergarten and first grade school children. J. Consulting and Clinical Psychol., 37, 38-43 (1971). 
Kirk, Samuel, Ethnic differences in psycholinguistic abilities. Except. Child, 39, 112-119 (1972).

Kolers, Paul A., Interlingual word associations. J. Verbal Learning and Verbal Behavior, 2, 291-300 (1963).

Kolers, Paul A., Bilingualism and bicodalism. Language and Speech, 8, 122-126 (1965).

Laosa, L., Swartz, J., and Moran, L., Word association structure among Mexican-American children. J. Social Psychol., 85, 7-15 (1971).

Macnamara, John, The linguistic independence of bilinguals. J. Verbal Learning and Verbal Behavior, 6, 729-736 (1967).

Nation, James, A vocabulary usage test. J. Psycholinguistic Research, 1, 221-231 (1972).

Perales, A. M., The audio-lingual approach and the Spanish-speaking student. Hispania, 48, 99-102 (1965).

Pinter, R., Comparison of American and foreign children on intelligence tests. J. Educational Psychol., 14, 292-295 (1933).

Politzer, R., An error analysis of the spoken English of MexicanAmerican pupils in a bilingual school and a monolingual school. Language Learning J., 23, 39-62 (1973).

Simmons, 0. G., Mutual images and expectations of Anglo-Americans and Mexican-Americans. Daedalus, 90, 286-299 (1961).

Williams, F., Ethnic stereotyping and judgments of children's speech. Speech Monogr., 38, 166-170 (1971). 
$\underline{A} \underline{P} \underline{P} \underline{E} \underline{N} \underline{D} \underline{I} \underline{\mathrm{C}} \underline{\mathrm{S}}$ 
APPENDIX A

ELIGIBILITY CRITERIA FOR TITIE 1M NELLIE MUIR SUMMER SCHOOL

Nonmigrant, Children

1. Must have resided in the area for at least one year.

2. Gross income for the family must be less than $\$ 4,000$ a year.

Migrant Children

1. Children who are presently living in migrant camps established in the area.

2. No maximum income level.

As per conference on July 7, 1975, with the program director of the Title 1M Nellie Muir Summer School, Woodburn, Oregon. 
APPENDIX $B$

ELIGIBIIITY/FEE SCALC (POTENTIAI RECIPIENTS) .

Children's Services Division

\begin{tabular}{|c|c|c|c|c|c|c|c|c|c|}
\hline \multirow{2}{*}{ FEE } & \multicolumn{2}{|c|}{ TOTAL } & \multirow{2}{*}{ FAHILY } & \multirow{2}{*}{$\frac{68055}{5}$} & \multirow{2}{*}{$\frac{I N C O N E}{6}$} & \multirow{2}{*}{$\frac{-8 r}{7}$} & \multirow{2}{*}{$\frac{F A H I L Y}{8}$} & \multicolumn{2}{|c|}{$512 E$} \\
\hline & 2 & 3 & & & & & & 9 & 10 \\
\hline $\begin{array}{r}0 \\
4 \\
8 \\
12 \\
16\end{array}$ & $\begin{array}{l}503 \\
504 \\
516 \\
528 \\
540\end{array}$ & $\begin{array}{l}577 \\
578 \\
593 \\
607 \\
622\end{array}$ & $\begin{array}{l}650 \\
651 \\
658 \\
685 \\
702\end{array}$ & $\begin{array}{l}736 \\
737 \\
757 \\
778 \\
799\end{array}$ & $\begin{array}{l}777 \\
778 \\
809 \\
823 \\
846\end{array}$ & $\begin{array}{l}868 \\
869 \\
895 \\
921 \\
947\end{array}$ & $\begin{array}{r}955 \\
957 \\
987 \\
1,016 \\
1.045\end{array}$ & $\begin{array}{l}1.020 \\
1.021 \\
1,053 \\
1,082 \\
1.111\end{array}$ & $\begin{array}{l}1,091 \\
1,082 \\
1,113 \\
1,145 \\
1,176\end{array}$ \\
\hline $\begin{array}{l}20 \\
24 \\
28 \\
32 \\
36\end{array}$ & $\begin{array}{l}552 \\
564 \\
576 \\
589 \\
601\end{array}$ & $\begin{array}{l}637 \\
65 \% \\
667 \\
.882 \\
697\end{array}$ & $\begin{array}{l}719 \\
736 \\
753 \\
759 \\
725\end{array}$ & $\begin{array}{l}820 \\
841 \\
851 \\
882 \\
903\end{array}$ & $\begin{array}{l}868 \\
891 \\
914 \\
936 \\
959 .\end{array}$ & $\begin{array}{r}973 \\
999 \\
1.025 \\
1.051 \\
1.073\end{array}$ & $\begin{array}{l}1.072 \\
3,059 \\
1.25 \\
1.53 \\
1.180\end{array}$ & $\begin{array}{l}1,140 \\
1,169 \\
1,199 \\
1,228 \\
1,257\end{array}$ & $\begin{array}{l}1,208 \\
1,239 \\
1,271 \\
1,303 \\
1,335\end{array}$ \\
\hline $\begin{array}{l}40 \\
44 \\
48 \\
52 \\
56\end{array}$ & $\begin{array}{l}613 \\
625 \\
637 \\
549 \\
661\end{array}$ & $\begin{array}{l}\prod_{111} \\
726 \\
741 \\
756 \\
771\end{array}$ & $\begin{array}{r}803 \\
-820 \\
837 \\
854 \\
871\end{array}$ & $\begin{array}{r}924 \\
945 \\
965 \\
985 \\
1.007\end{array}$ & $\begin{array}{l}982 \\
1,004 \\
1.027 \\
1.050 \\
1.071\end{array}$ & $\begin{array}{l}1,097 \\
1,121 \\
i, 145 \\
1,169 \\
1,193\end{array}$ & $\begin{array}{l}1,207 \\
i, 234 \\
i, 251 \\
i, 289 \\
1,316\end{array}$ & $\begin{array}{l}1,289 \\
1,322 \\
1,354 \\
i, 355 \\
1,419\end{array}$ & $\begin{array}{l}1.368 \\
1.400 \\
1.432 \\
1.454 \\
1.456\end{array}$ \\
\hline $\begin{array}{l}60 \\
64 \\
68 \\
72 \\
76\end{array}$ & $\begin{array}{l}673 \\
685 \\
697 \\
709 \\
721\end{array}$ & $\begin{array}{l}786 \\
800 \\
815 \\
830 \\
845\end{array}$ & $\begin{array}{l}888 \\
904 \\
92 ! \\
938 \\
955\end{array}$ & $\begin{array}{l}1,028 \\
1,049 \\
1,068 \\
1,087 \\
1,106\end{array}$ & $\begin{array}{l}1.091 \\
1.112 \\
1,133 \\
1.154 \\
1.175\end{array}$ & $\begin{array}{l}1,217 \\
1,241 \\
1,265 \\
1,290 \\
1,316\end{array}$ & $\begin{array}{l}1.344 \\
1.374 \\
1.404 \\
3.434 \\
7.454\end{array}$ & $\begin{array}{l}1,451 \\
1,433 \\
1,516 \\
1,548 \\
1,580\end{array}$ & $\begin{array}{l}1.523 \\
1.565 \\
1.651 \\
1.639 \\
1.574\end{array}$ \\
\hline $\begin{array}{l}80 \\
84 \\
88 \\
92 \\
96\end{array}$ & $\begin{array}{l}733 \\
745 \\
757 \\
769 \\
781\end{array}$ & $\begin{array}{l}250 \\
875 \\
830 \\
904 \\
919\end{array}$ & $\begin{array}{r}972 \\
989 \\
1.005 . \\
1.023 \\
1.040\end{array}$ & $\begin{array}{l}1.126 \\
1.145 \\
1.165 \\
1.185 \\
1.205\end{array}$ & $\begin{array}{l}1,198 \\
1,220 \\
1,242 \\
1,264 \\
1.286\end{array}$ & $\begin{array}{l}1,343 \\
1,369 \\
1.395 \\
1,821 \\
1.448\end{array}$ & $\begin{array}{l}1,494 \\
1,524 \\
1,554 \\
1,524 \\
1,614\end{array}$ & $\begin{array}{l}1,613 \\
1,645 \\
1,677 \\
1,710 \\
1,742\end{array}$ & $\begin{array}{l}1,711 \\
1.748 \\
1,724 \\
1.821 \\
1.857\end{array}$ \\
\hline $\begin{array}{l}100 \\
104 \\
108 \\
112 \\
116\end{array}$ & $\begin{array}{l}793 \\
805 \\
817 \\
829 \\
891\end{array}$ & $\begin{array}{l}934 \\
549 \\
564 \\
y 79 \\
993\end{array}$ & $\begin{array}{l}1.057 \\
1.073 \\
1.030 \\
1.107 \\
1.127\end{array}$ & $\begin{array}{l}1,226 \\
1,246 \\
1,267 \\
1,287 \\
1,308\end{array}$ & $\begin{array}{r}1,309 \\
1,331 \\
?, 353 \\
1,375 \\
1,398\end{array}$ & $\begin{array}{l}1,474 \\
1,500 \\
1,526 \\
1,553 \\
1,579\end{array}$ & $\begin{array}{l}1,644 \\
1, .775 \\
1,705 \\
1,735 \\
1.765\end{array}$ & $\begin{array}{l}1,774 \\
1,801 \\
1,239 \\
1,871 \\
1,904\end{array}$ & $\begin{array}{l}1,094 \\
1,930 \\
1,967 \\
2,003 \\
2,040\end{array}$ \\
\hline $\begin{array}{l}120 \\
124 \\
123 \\
132\end{array}$ & $\begin{array}{l}854 \\
850 \\
870 \\
890\end{array}$ & $\begin{array}{l}1,009 \\
1,024 \\
1,039 \\
1,054\end{array}$ & $\begin{array}{l}1.147 \\
1,168 \\
1,168 \\
1,208\end{array}$ & $\begin{array}{l}1.328 \\
1.339 \\
1.359 \\
1.390\end{array}$ & $\begin{array}{l}1.420 \\
1.4=2 \\
1.464 \\
1.425\end{array}$ & $\begin{array}{l}1.505 \\
1.631 \\
1.658 \\
1.684\end{array}$ & $\begin{array}{l}1.795 \\
1.825 \\
1.855 \\
1,805\end{array}$ & $\begin{array}{l}1.536 \\
1.968 \\
2.001 \\
2.033\end{array}$ & $\begin{array}{l}2.076 \\
2.1: 3 \\
2.149 \\
2,185\end{array}$ \\
\hline Ișible & $893^{\circ}$ & 1.058 & 1,213 & 1.396 & 1,492 & 1,691 & 1,893 & 2,041 & 2,1904 \\
\hline
\end{tabular}

I:A lee ls charred reg̈riless of the number of chlldren in care but in no ease xil 1t exseed the actual cost of care. Families with incones $a t$ or below the rinst line of income :igures will pay no fee. In cases where court authorize? deductions are weri:fred to be maje from the applicant's pay the amount of te-

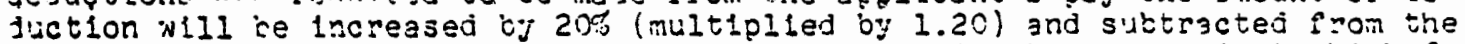
gross incone fizure. The new gross income fljure is the one ajalnst which fees are applied. 


\section{APPENDIX C}

MIRA RESPONSE SHEET

Name

Birthdate

Address
School

Examiner

Date of Examination

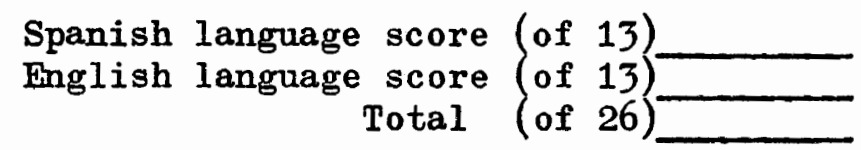

Dominant Ianguage

Instructions: "Ensename -" Check correct response. Circle incorrect response.

1. mama

sofa

papas

papa

2. casa

agua

mona

gato

3. leche

carro

zapatos

perro

4. pelo

trocke

pan

boca

5. silla

$\sin$

reloj

calcetine

6. plato

pajaro

pantalones

pelota
7. pierna

mija

mijo

libro
8. puerta camisa dedo flor

9. ojo mano nariz oido

10. arbol hielera cuchara vestido

11. stufa mesa huevo cama

12. tualla jabon vaso dinero

13. negro amarillo

rojo blanco 


\section{APPENDIX C (cont.)}

English

Instructions: "Show me___ Check correct response. Circle incorrect response.

1. swing

table

book

sandwich

2. sad

chair

pig

happy

3. cow

bicycle

hamburger

milk

4. T.V. chicken tree

water

5. give

baby

bird

boy

6. eraser

shirt

clock

pencil
7. star

door

hot dog

scissors

8. candy

horse

ball

window

9. reading

banana

pants

running

10. gate

flag

sock

dress

11. ice cream

dog

car

banana

12. telephone

shoes

bell

window

13. black

yellow

red

white 


\section{APPENDIX D}

\section{PILOT STUDY*}

English word list

$$
\begin{aligned}
& \text { All Spanish } \\
& \text { Response given }
\end{aligned}
$$

No. Responses by 6-yr.-old MexicanAmerican children

Sandwich
Happy
Bicycle
T.V.
Baby
Pencil
Hot dog
Candy
Punning
Sock
Ice cream
Shoes
Red

\section{9}

1

1

2

5

9

9

2

7

1

8

9

1

8

9

1

8

2

7

9

1

8

*A pilot study was conducted, using nine six-year-old Mexican-American children, to translate into Spanish the English word list on the MIRA. The Spanish words listed are the responses given by these children; the response given most often was used on the modified MIRA.

**Words used on the Part II Spanish portion of the MIRA. 


\section{APPENDIX E}

MODIFIED MIRA TEST

NAME

$\mathrm{AGE}$

English

Part I

1. Sandwich

2. Happy

3. Bicycle

4. T.V.

5. Baby

6. Pencil

7. Hot dog

8. Candy

9. Running

10. Sock

11. Ice cream

12. Shoes

13. Red

DATE

Spanish

Part II

1. Sanwich

2. Contendo

3. Bicikleta

4. Television

5. Bebi

6. Lapiz

7. Hot dog

8. Dulce

9. Corriendo

10. Calcetine

11. Nieve

12. Zapatos

13. Ro jo (colorado)

SCORE

Part II

1. Mama

2. Cat

3. Car

4. Mouth

5. Chair

6. Ball

7. His

8. Flower

9. Eye

10. Tree

11. Bed

12. Glass

13. Yellow

SCORE

Part I

1. Mama

2. Gato

3. Carro

4. Boca

5. Silla

6. Pelota

7. Mijo

8. Flor

9. 0 jo

10. Arbol

11. Cama

12. Vaso

13. Amarillo

SCORE

TOTAL 


\section{APPENDIX F}

\section{PEABODY PICTURE VOCABULARY TEST}
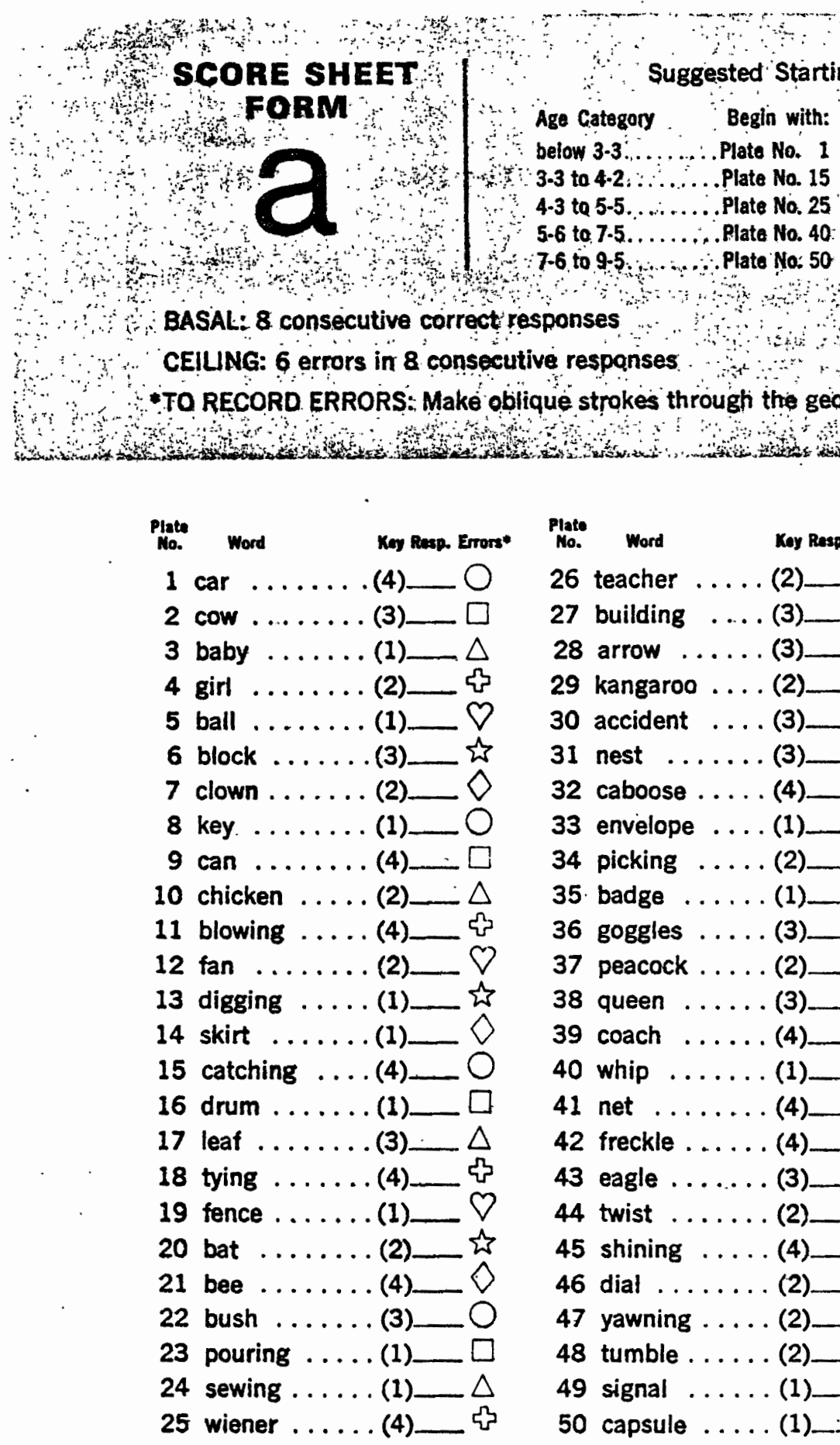

\section{Ya}

g Points (see manual page 8).

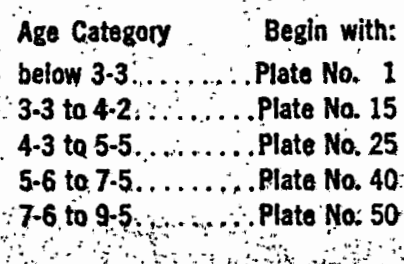

Age Category Begin with: 9.6 to 11.5 .... Plate No. 60 11.6 to $13.5 \ldots$. . . Plate No. 70 13-6 to $15-5$. . . . Plate No. 80 15-6: to 17-5. . .....Plate No. 90 abave 17-6... . Plate Na. 100

BASAL: 8 consecutive correct responses

8 consecutive respanses

TO RECORD ERRORS: Make oblique strokes through the geometric figures Every eighth figure is idel

\begin{tabular}{|c|c|}
\hline $\begin{array}{l}\text { Plato } \\
\text { No. }\end{array}$ & Koy Resp. \\
\hline 26 & teacher .... \\
\hline 27 & building $\ldots .(3)$ \\
\hline 28 & arrow ......(3) \\
\hline 29 & kangaroo ..... (2) \\
\hline 30 & accident $\ldots .(3)$ \\
\hline 31 & nest $\ldots \ldots \ldots(3)$ \\
\hline 32 & caboose .... (4) \\
\hline 33 & envelope $\ldots$. (1) \\
\hline 34 & picking $\ldots \ldots$ (2) \\
\hline 35 . & badge $\ldots \ldots$ (1) \\
\hline 36 & goggles . . . . (3) \\
\hline 37 & peacock . . . . (2) \\
\hline 38 & queen $\ldots . . .(3)$ \\
\hline 39 & coach $\ldots . .(4)$ \\
\hline 40 & whip $\ldots \ldots$ (1) \\
\hline 41 & net $\ldots \ldots \ldots$ (4) \\
\hline 42 & freckle ...... (4) \\
\hline 43 & eagle ....... (3) \\
\hline 44 & twist $\ldots \ldots \ldots(2)$ \\
\hline 45 & shining $\ldots \ldots(4)$ \\
\hline 46 & dial $\ldots \ldots \ldots(2)$ \\
\hline 47 & yawning .... (2) \\
\hline 48 & tumble ...... (2) \\
\hline 49 & signal ...... (1) \\
\hline 50 & capsule .... \\
\hline
\end{tabular}

Plate

No.

Xoy Resp. Errors

51 submarine ... (4)

52 thermos ......(4)

53 projector ....(3)

54 group ...... (4)

55 tackling ......(3)___ is

56 transportation (1)___ $>$

57 counter ......(1)__ $\bigcirc$

58 ceremony ..... (2)

59 pod ....... (3)__ $\triangle$

60 bronco ..... (4)__ 々

61 directing .....(3)__ $\nabla$

62 funnel ......(4)__ i

63 delight ......(2)__ 0

64 lecturer ......(3)___ $\bigcirc$

65 communication (2)__ $\square$

66 archer ......(4)__ $\triangle$

67 stadium ......(1)__

68 excavate ....(I) _ $\_$(

69 assaulting ....(4) ___ it

70 stunt ........(1)___

71 meringue .....(1)___

72 appliance ....(3)__ $\square$

73 chemist ..... (4)__ $\triangle$

74 arctic .......(3) _ ह

75 destruction ... (4)__ $\bigcirc$ 
APPENDIX F

PEABODY PICTURE VOCABULARY TEST (cont.)

\section{RAW SCORE CALCULATIONS}

Ceiling item
Less errors
Raw score

itical to facilitate the determination of the basal or ceiling.

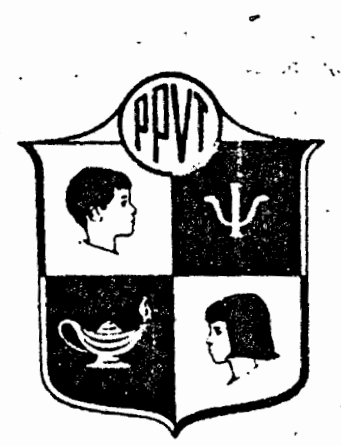

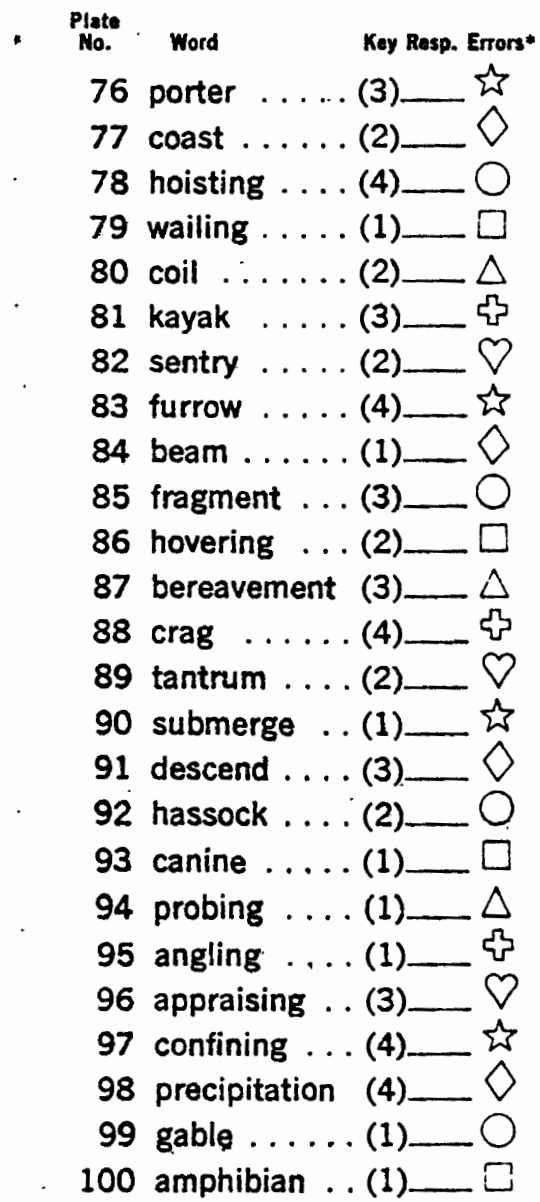

\begin{tabular}{|c|c|c|}
\hline $\begin{array}{l}\text { Piate } \\
\text { Mo. }\end{array}$ & Word & Key Resp. Errors" \\
\hline 101 & graduated & (3) \\
\hline 102 & hieroglyphic & $\cdot(2)$ \\
\hline 103 & orate .... & (1) \\
\hline 104 & cascade . & . (3) \\
\hline 105 & illumination & . (4) \\
\hline 106 & nape .... & . (1) \\
\hline 107 & genealogist & . (2) \\
\hline 108 & embossed & (2) \\
\hline 109 & mercantile. & (4) \\
\hline 110 & encumbered &.$(2)$ \\
\hline 111 & entice .. & . (4) \\
\hline 112 & concentric & (3) \\
\hline 113 & vitreous. & (3) \\
\hline 114 & sibling .... & (1) \\
\hline 115 & machete & (2) \\
\hline 116 & waif .... & (4) \\
\hline 117 & cornice & (1) \\
\hline 118 & timorous & (3) \\
\hline 119 & fettered & (1) \\
\hline 120 & tartan & (2) \\
\hline 121 & sulky .... &.$(3) \_\square$ \\
\hline 122 & obelisk .. & (4) $\triangle$ \\
\hline 123 & ellipse . . & (2) \\
\hline 124 & entomology & $(2) \_\nabla$ \\
\hline 125 & bumptious & . (4)_国 \\
\hline
\end{tabular}

Plate

Plate Word Key Resp. Errors*

126 dormer .... (2)

(2)

127 coniferous ... (2)

128 consternation (4)

129 obese ..... (3)

130 gauntlet ....

131 inclement ...(1)

132 cupola ...... (1)

8

133 obliterate ... (2)

(1) - - i

134 burnishing ... (3)

135 bovine ..... (1)

(3)

136 eminence...

137 legume ..... (3)

(1) _ $\square$

138 senile ..... (4)

(3)__

139 deleterious . (2) _ is

140 raze .... . . (4)

141 ambulation .

(2)

142 cravat ..... (1)

143 impale ...... (2)

(1)__ $\square$

144 marsupial ...(4) \{

145 predatory ... (3)

146 incertitude...(1)__ is

147 imbibe .....

148 homunculus.

(2) ___ $>$

149 cryptogam . .

(4) []

150 pensile .... (3)

(3)_ـ $\triangle$ 
APPENDIX G

\title{
PERMISSION REQUEST
}

\section{Dear Parent:}

I am a graduate student at Portland State University and $I^{\prime} m$ trying to find out the amount of Spanish and English a preschool fouror five-year-old child knows. I have the approval of Title $1 \mathrm{M}$ Sumer School, Nellie Miur, Woodburn, Oregon, and with your permission I would like to talk to your child and ask him or her some questions in English and Spanish.

In no way will your child's name be used in this study. Will you please help me by signing the slip below and sending it to school with your child.

\section{Thank you,}

\author{
Amparo Abila \\ Graduate Student \\ Portland State University
}

I give my permission for Amparo Abila to ask my child questions in Spanish and English.

\section{Parent's Signature}

Queremos su consentimento para hacer preguntas en Ingles y Espanol a sus hijos. 


\title{
APPENDIX H
}

\section{PERMISSION REQUEST}

\section{Dear Parent:}

I am a graduate student at Portland State University and I am trying to find out the amount of language a four- or five-year-old child knows. I have the approval of this Child Care Center and with your permission I would like to talk to your child and ask him or her to point to the pictures of the words I say, for example, car, dog, etc.

In no way will your child's name be used in this study. Will you please help me by signing the slip below and giving it to one of the teachers.

Thank you,

\author{
Amparo Abila \\ Graduate Student \\ Portland State University
}

I give my permission for Amparo Abila to give my child a vocabulary test.

Parent's Signature 